\title{
Personal resources and satisfaction with life in Marfan syndrome patients with aortic pathology and in abdominal aortic aneurysm patients
}

\author{
Michał-Goran Stanišić ${ }^{1}$, Teresa Rzepa ${ }^{2}$, Alicja Gawrońska², Przemysław Kubaszewski ${ }^{2}$, Maciej Putowski $^{3}$, \\ Sebastian Stefaniak ${ }^{4}$, Bartłomiej Perek ${ }^{4}$
}

${ }^{1}$ Department of Vascular and Endovascular Surgery, Angiology and Phlebology, Poznan University of Medical Sciences, Poland

${ }^{2}$ University of Social Sciences and Humanities, Department of Poznan, Poland

3! Faculty of Medicine with Dentistry Division, Medical University of Lublin, Poland

${ }^{4}$ Department of Cardiac Surgery and Transplantology, Poznan University of Medical Sciences, Poland

Kardiochirurgia i Torakochirurgia Polska 2018; 15 (1): 27-30

\begin{abstract}
Introduction: Whether or not the source of aortic pathology is Marfan syndrome (MFS) or other processes leading to development of abdominal aorta aneurysms (AAA), the awareness of pathology may lead to an emotional upset and low assessment of satisfaction with life.

Aim: To assess, in regard to MFS patients with aortic pathology and to abdominal aortic aneurysm patients: 1) whether or not self-efficacy (SE) and health locus of control (HLoC) affect the patients' satisfaction with life; 2) whether the two groups of patients differ in terms of mental dispositions.

Material and methods: The study population consisted of 16 MFS patients with aortic pathology and 16 AAA patients, 9 men and 7 women in each group. The mean age of the MFS patients was $28.5 \pm 8.214$, and of the AAA patients $64.25 \pm 7.019$. The following scales were applied: Generalized Self-Efficacy Scale, Satisfaction With Life Scale, Multidimensional Health Locus of Control Scale. Results: Abdominal aorta aneurysms patients compared to MFS patients gave a higher rating for SE $(M D=33.94$ and $M D=29.56)$, internal health locus of control $(M D=25.00$ and $M D=21.13)$, external personal HLoC $(M D=24.50$ and $M D=19.25)$, external impersonal HLOC $(M D=23.06$ and $M D=18.25)$, and satisfaction with life $(M=22.06$ and $M=20.13)$. Internal and external HLoC were significantly lower in MFS patients compared to AAA patients.

Conclusions: In patients with aortic diseases, special attention must be paid to the state of personal resources (PR). Interactions made by medical professionals should focus on enhancing PR supporting the patients' self-knowledge on their SE. This will help to improve their satisfaction with life and form a positive attitude to the illness.
\end{abstract}

Key words: personal resources, aortic dissection, Marfan syndrome, abdominal aorta aneurysms.

\section{Streszczenie}

Wstęp: Niezależnie od tego, czy źródłem choroby aorty jest zespół Marfana (MFS) lub inne procesy prowadzące do rozwoju tętniaków aorty brzusznej (AAA), świadomość choroby może prowadzić do zaburzeń emocjonalnych oraz niskiej oceny satysfakcji z życia.

Cel: Ocena pacjentów z MFS z patologią aorty oraz pacjentów z tętniakiem aorty brzusznej: 1) czy skuteczność własna (SE) i umiejscowienie kontroli zdrowia (HLoC) wpływają na zadowolenie pacjentów z życia; 2) czy obie grupy pacjentów różnią się pod względem dyspozycji psychicznej.

Materiat i metody: Badaniem objęto 16 chorych z MFS z patologią aortalną oraz 16 pacjentów z AAA. W każdej grupie było 9 mężczyzn i 7 kobiet. Średni wiek pacjentów z MFS wynosit $28,5 \pm 8,214$ roku, a pacjentów z AAA - 64,25 $\pm 7,019$. Zastosowano następujące skale: Skalę uogólnionej własnej skuteczności, Wielowymiarową skalę umiejscowienia kontroli zdrowia oraz Skalę satysfakcji z życia.

Wyniki: Pacjenci z AAA oceniali swoją SE wyżej niż pacjenci z MFS ( $M D=33,94$ i $M D=29,56)$, HLoC wewnętrzne $(M D=25,00$ i $M D=21,13)$, HLoC zewnętrzne, zależne od wpływu innych $(M D=24,50 \mathrm{i} M D=19,25)$, HLoC zależne od przypadku $(M D=23,06$ i $M D=18,25)$ oraz zadowolenie z życia $(M=22,06$ i $M=20,13)$. Wewnętrzne i zewnętrzne HLoC były znacząco niższe u pacjentów z MFS w porównaniu z pacjentami z AAA.

Wnioski: U pacjentów z chorobami aorty należy zwrócić szczególną uwagę na stan zasobów osobistych (PR). Działania prowadzone przez pracowników ochrony zdrowia powinny skupiać się na edukacji i wspieraniu pacjentów. Pomoże to zwiększyć satysfakcję pacjentów z życia oraz poprawi ich podejście do choroby.

Słowa kluczowe: zasoby osobiste, rozwarstwienie aorty, zespół Marfana, tętniak aorty brzusznej.

Address for correspondence: Maciej Putowski, I Faculty of Medicine with Dentistry Division, Medical University of Lublin, 1 Raclawickie St, 20-059 Lublin, Poland, phone: +48 502321 226, e-mail: putowski.maciek@gmail.com

Received: 22.10.2017, accepted: 2.01.2018. 


\section{Introduction}

Aortic aneurysms and dissections are the main pathologies treated by teams of vascular and cardiac surgeons. As radical surgery is not possible here, the basic way to treat the pathologies and thus to prevent premature death is surgical (open and endovascular) treatment. Slightly arbitrarily, aortic pathologies are divided into those regarding the abdominal aorta and the thoracic aorta. Due to the diagnostic and treatment similarities, this article will look at abdominal aorta aneurysms and Marfan syndrome (MFS) involving thoracic and abdominal aorta aneurysms and dissections. Abdominal aortic aneurysm is the $12^{\text {th }}$ $13^{\text {th }}$ cause of death in the male population. Abdominal aortic aneurysm tends to be asymptomatic practically until its rupture [1]. Elective surgery of abdominal aortic aneurysm is done when its diameter exceeds $55 \mathrm{~mm}$ in men and $52 \mathrm{~mm}$ in women. Despite improved techniques of open surgery and cardiological risk reduction following introduction of endovascular aneurysm repair (EVAR), aneurysm treatment is still associated with a relatively high risk of postoperative complications, including 30/90-day mortality [1]. Currently, there are two ways of abdominal aortic aneurysm surgical treatment. Open surgery, practised for 70 years, has been a successful way to eliminate an aneurysm from the circulatory system. Due to the cardiological risks associated with open surgery, in the past some patients were not qualified for elective operations and underwent surgical treatment only in case of rupture symptoms [1].

Marfan syndrome is a genetically conditioned, autosomal dominant, inherited disease of connective tissue. It leads to damage of elastic fibres and disorders in production of elastin and of connective tissue ground substance. In the case of ca. $20 \%$ of MFS patients their parents and ancestors are completely healthy; therefore the disease may be caused by a recent gene mutation [2]. The mutation pertains to the FBN1 gene, chromosome 15, encoding the protein fibrillin 1 , which is decisive for the correct binding of the transforming growth factor $\beta$ (TGF- $\beta$ ) protein in connective tissue, and indispensable for correct formation of extracellular matrix [3].

The condition is characterised by connective tissue defects in all organs and tissues. However, the most characteristic symptoms are found in the organs of vision (ectopia lentis, myopia and astigmatism), the osteoarticular system (excessive articulatory mobility, thoracic and spinal column deformations) and the cardiovascular system (aortic aneurysms, aneurysms in other vessels, aorta dissection, mitral valve leaflets prolapse) [4]. Neurological symptoms (balance disorders, coordination disorders, somnolence, hypotonia) affect the psychophysical functioning and the quality of patients' lives [5-8]. The most serious clinical manifestation of MFS is aortic aneurysm or acute aortic dissection [9]. Prior to the era of elective surgery that consists in replacing the aortic valve along with the aortic bulb (i.e. Bentall procedure), 2/3 of all MFS patients died as a result of acute aortic dissection, usually at a young age [10].
Apart from numerous organic defects, MFS is also associated with specific adaptation problems. This is because the disease affects the psychosocial functioning of MFS patients from a very young age, exposing them to stress and anxiety about being stigmatised, which makes them worry about their future. Even those who have learnt to live with this genetic disease can experience anger and frustration, as they repeatedly realise they are different from others as a result of the specific phenotype. They can even feel scared and guilty, because they may pass on or may have already passed on the faulty gene to their descendants [11].

Regardless of their age and whether or not the source of aorta pathology is MFS or inflammatory processes leading to development of abdominal aorta aneurysms unrelated to MFS, the awareness of a life-threatening aortic pathology may lead to an emotional upset that is difficult to stabilise, and low satisfaction with life.

The mental condition of patients with thoracic and abdominal aorta pathology requires continuous activation of personal resources comprising psychological skills that are necessary to effectively cope with a chronic disease and everyday life requirements. Coping with information on the risk resulting from progression of the disease and the need to make a decision on undergoing surgical treatment requires occasional activation of similar resources by patients with abdominal aorta aneurysms. The personal resources include mental dispositions that are particularly important in both diseases: self-efficacy and health locus of control, which enable patients to cope with the stress associated with a serious disease and its consequences [12]. Its adaptive value is reinforced by a positive assessment of one's satisfaction with life.

Self-efficacy is based on the conviction that one is able to meet one's objectives, i.e. to carry out one's tasks even in unforeseeable and stress-inducing conditions [13]. The health locus of control is understood as a generalised expectation that any events in life are a result of either external forces or own efforts and personal control [14]. The internal health locus of control is connected with taking personal responsibility for one's health. However, the health locus of control may also be external: patients may see it as dependent either on other people (especially health professionals) or on one's fate or chance [15]. As for satisfaction with life, it relates to a set of factors such as physical health, mental condition, degree of independence, relations with the people around them, and functioning in their social and occupational roles [16].

\section{Aim}

As the research studies completed so far have not addressed the issue whether and how personal resources affect satisfaction with life experienced by MFS patients and abdominal aortic aneurysm patients, this study aimed to find out:

1) whether or not the key components of personal resources, such as self-efficacy and health locus of control, affect the patients' satisfaction with life; 
2) whether the two groups of patients differ in terms of the discussed mental dispositions.

\section{Material and methods}

With consent granted by the Research Ethics Committee, in the period from March to October 2014, 16 MFS patients and 16 abdominal aorta aneurysm (AAA) patients were examined. There were 9 men and 7 women in each group. Due to the specific nature of both conditions, the subjects differed in terms of age, i.e. the mean age of the MFS patients was $28.5 \pm 8.214$ years, and of the AAA patients $64.25 \pm 7.019$ years.

In view of the purpose of the research study, 3 scales were applied, which were completed by the subjects in the following order:

1. Generalized Self-Efficacy Scale (GSES, by: R. Schwarzer, M. Jerusalem; adapted by Z. Juczyński), composed of 10 statements and measuring the level of general personal conviction regarding the individual's efficacy in handling tough situations [17];

2. Satisfaction With Life Scale (SWLS, by: E. Diener, R.A. Emmons, R.J. Larson, S. Griffin; adapted by: Z. Juczyński), composed of 5 statements and measuring the generalised feeling of satisfaction with life so far [17];

3. Multidimensional Health Locus of Control Scale (MHLC, by: K.A. Wallston, B.S. Wallston, R. De Vellis; adapted by: Z. Juczyński), composed of 18 statements and aimed at specifying their expectations in three aspects of health locus of control [17]. Thus, the study participant indicates whether their own health is controlled: 1) by them (internal dimension); 2) by other individuals, especially health professionals (external personal dimension); 3) by fate/ chance (external impersonal dimension).

Scales 1 and 3 were used for measuring mental dispositions constituting part of personal resources (self-efficacy, health locus of control), and scale 2 - to assess satisfaction with life.

\section{Statistical analysis}

The statistical analysis of the results was done by means of IBM SPSS Statistics 22 software. To assess the normality of distribution of the analysed variables, the Shapiro-Wilk test was applied. In order to determine the strength of correlation between the variables, Pearson's correlation coefficient $(r)$ was applied, and the between-subjects factors were verified by means of variance analysis in the multivariable model.

\section{Results}

Despite the considerable age difference, the AAA patients obtained higher scores with regard to all the studied mental dispositions, compared to the MFS patients. The AAA patients rated the following higher than the MFS patients: self-efficacy (respectively: $M D=33.94 \pm 5.247$ and $M D=29.56 \pm 5.966)$, internal health locus of control (respectively: $M D=25.00 \pm 3.386$ and $M D=21.13 \pm 4.272$ ), external personal health locus of control (respectively: $M D=24.50 \pm 4.761$ and $M D=19.25 \pm 6.039)$, external impersonal health locus of control (respectively: $M D=23.06$ \pm 4.640 and $M D=18.25 \pm 3.890$ ), and satisfaction with life (respectively: $M=22.06 \pm 6.475$ and $M=20.13 \pm 5.353$ ).

Among the MFS patients, satisfaction with life showed the strongest positive correlation with self-efficacy $(p<0.001)$ and an average positive correlation with external personal health locus of control ( $p<0.045)$. A strong positive correlation was found between the internal and external personal health locus of control $(p<0.008)$ and an average positive correlation was found between internal health locus of control and self-efficacy $(p<0.045)$.

Among the AAA patients, there was a positive, strongerthan-average correlation between satisfaction with life, external personal $(p<0.042)$ and impersonal $(p<0.15)$ health locus of control; these factors showed a very strong and positive correlation $(p<0.002)$. Moreover, a positive, strongerthan-average correlation was found between internal health locus of control and self-efficacy $(p<0.016)$, and a similar correlation was found between age and gender $(p<0.046)$.

It was found that self-efficacy and internal and external (personal and impersonal) health locus of control were statistically significantly lower in the MFS patients than the AAA patients. Out of the above-mentioned factors, the most significant in terms of explaining variability between the groups proved to be the external impersonal health locus of control (25.2\%), followed by the internal (21.2\%) and external personal health locus of control (19.9\%) and selfefficacy (13.9\%). No statistically significant difference was found between the groups in terms of satisfaction with life assessment.

\section{Discussion}

The research studies done so far have focused primarily on identifying emotions experienced by MFS and AAA patients. In this context, the identified emotions included stress, anger, sadness, anxiety and depression as well as decreased satisfaction with life along with psychophysical functioning disorders [5-8, 11, 18-21]. However, there has been no research into the question whether activation of personal resources may mitigate the negative psychosocial effects of both diseases, thus affecting the patients' satisfaction with life. This research study showed it was possible, even though the study involved only a small number of patients from both groups.

The MFS and AAA patients graded their satisfaction with life similarly - as higher than average. This proved that both groups coped with the difficult, stress-inducing situations rather effectively, applying to this end their personal resources. The MFS patients relied mainly on their self-efficacy, as on the basis of their experience gained so far, they already knew which techniques were the most effective for comfortable functioning in the social context. In their coping with the disease and stress-inducing everyday problems, they also rely on support and assistance from health professional and family [22]. 
The AAA patients, for whom the news of the disease was unexpected and seemingly accidental, rely predominantly on the belief in help and support from medical professionals and family, and they trust that the unexpected bad luck will take a turn for the better [23, 24].

It was found that the AAA patients were more determined to activate and use their personal resources, as their difficult situation in life resulting from the unexpected diagnosis of abdominal aortic aneurysm was only temporary and could be faced as a challenge, i.e. a problem to be solved. Thus, the $21.2 \%$ of the difference between them and the MFS patients could be explained by a different approach to taking personal responsibility for one's health (internal health locus of control), and $19.9 \%$ by relying on medical professionals (external personal dimension of health locus of control). This result also indicates that the MFS patients used their personal resources more prudently and sparingly. Therefore, the scores obtained by them with regard to all the compared factors were lower than in the AAA patients, and the difference between the groups was the smallest in the area of self-efficacy (13.9\%). The most significant factor to explain the variability between patient groups was external impersonal dimension of health locus of control (25.2\%), standing for faith in a significant impact of chance, fate, and bad luck. This idea was shared mainly by the AAA patients, who due to the unexpected and unfavourable diagnosis could still be stuck in the initial stages of the reaction to the news of a serious disease, i.e. the shock or denial stages [25].

Moreover, strong positive correlations were found between the individual components of the personal resources, which not only means they were well chosen, but first and foremost proves their significant value for improving the functioning of the patients in both groups. This is because both relying on self-efficacy and other individuals (particularly on medical professionals) and personal responsibility for health make it possible to effectively cope with difficult and stress-inducing situations in life [12, 18, 24].

\section{Conclusions}

In the case of patients with aorta diseases, special attention must be paid to the state of their personal resources and the possibility of their activation. Any interactions made by medical professionals, therapists, family members, etc., should focus on enhancing the resources. This is because any actions that support the patients' self-knowledge on their self-efficacy, personal responsibility for health, and possibility to receive help from their family and medical professionals help them improve their satisfaction with life and form a positive attitude to the illness, which in turn has a beneficial effect on the treatment and recovery process.

\section{Disclosure}

Authors report no conflict of interest.

\section{References}

1. Moll FL, Powell JT, Fraedrich G, Verzini F, Haulon S, Waltham M, van Herwaarden JA, Holt PJ, van Keulen JW, Rantner B, Schlösser FJ, Setacci F, RicCo JB; European Society for Vascular Surgery. Management of abdominal aortic aneurysms clinical practice guidelines of the European Society for Vascular Surgery. Eur J Vasc Endovasc Surg 2011; 41 Suppl 1: S1-S58.

2. Jondeau G, Michel JB, Boileau C. The translational science of Marfan syndrome. Heart 2011; 97: 1206-1214.

3. Dietz HC, Loeys B, Carta L, Ramirez F. Recent progress towards a molecular understanding of Marfan syndrome. Am J Med Genet C Semin Med Genet 2005; 139C: 4-9.

4. Bruno L, Tredici S, Mangiavacchi M, Colombo V, Mazzotta GF, Sirtori CR. Cardiac, skeletal, and ocular abnormalities in patients with Marfan's syndrome and in their relatives. Comparison with the cardiac abnormalities in patients with kyphoscoliosis. Br Heart J 1984; 51: 220-230.

5. Dyhdalo K, Farver C. Pulmonary histologic changes in Marfan syndrome: a case series and literature review. Am J Clin Pathol 2011; 136: 857-863.

6. McAllister M, Davies L, Payne K, Nicholls S, Donnai D, MacLeod R. The emotional effects of genetic diseases: implications for clinical genetics. Am J Med Genet A 2007; 143A: 2651-2661.

7. Rand-Hendriksen S, Sørensen I, Holmström H, Andersson S, Finset A. Fatigue, cognitive functioning and psychological distress in Marfan syndrome, a pilot study. Psychol Health Med 2007; 12: 305-313.

8. Peters, KF, Kong F, Hanslo M, Biesecker BB. Living with Marfan syndrome III: quality of life and reproductive planning. Clin Genet 2002; 62: 110-120.

9. Loeys BL, Dietz HC, Braverman AC, Callewaert BL, De Backer J, Devereux RB, Hilhorst-Hofstee Y, Jondeau G, Faivre L, Milewicz DM, Pyeritz RE, Sponseller PD, Wordsworth P, De Paepe AM. The revised Ghent nosology for the Marfan syndrome. J Med Genet 2010; 47: 476-485.

10. Silverman DI, Burton KJ, Gray J, Bosner MS, Kouchoukos NT, Roman MJ, Boxer M, Devereux RB, Tsipouras P. Life expectancy in the Marfan syndrome. Am J Cardiol 1995; 75: 157-160.

11. Peters KF, Apse KA, Blackford A, McHugh B, Michalic D, Biesecker BB. Living with Marfan syndrome: coping with stigma. Clin Genet 2005; 68: 6-14.

12. Antonovsky A. The sense of coherence as a determinant of health. In: Behavioral Health: A Handbook of Health Enhancement and Disease Prevention. JD Matarazzo, NE Miller (eds.). Wiley-Interscience, New York 1984.

13. Bandura A. Self-efficacy mechanism in human agency. American Psychologist 1982; 37: 122-147.

14. Rotter JB. Generalized expectancies for internal versus external control of reinforcement. Psychol Monogr 1966; 80: 1-28.

15. Wallston KA, Stein MJ, Smith CA. Form C of the MHLC Scales: a conditionspecific measure of locus of control. J Pers Assess 1994; 63: 534-553.

16. Pavot W, Diener E. The Satisfaction with Life Scale and the emerging construct of life satisfaction. J Positiv Psychol 2008; 3: 137-152.

17. Juczyński Z. Measurement Tools in Health Promotion and Health Psychology. Psychological Test Lab of the Polish Psychological Association, Warsaw 2001.

18. Janowski K, Steuden S. Biopsychosocial aspects of health and disease. CPPP Scientific Press, Lublin 2009.

19. Rzepa T, Stanisić M. Attitude to one's illness vs. attitude to a surgical operation, displayed by patients diagnosed with asymptomatic abdominal aortic aneurysm and asymptomatic internal carotid artery stenosis. Int Ang 2012; 31: 376-385.

20. Baune BT, Unwin SJ, Quirk F, Golledge J. Neuropsychiatric symptoms in patients with aortic aneurysm. PLoS One 2011; 6: e22632.

21. Mall Gd, Kesserwane R, Hennebry TA, Benjamin AB. Anxiety disorders: aortic aneurysm in the differential? www.psychiatrictimes.com/articles/anxietydisorders-aortic-aneurysym-in-the-differential [Available at: 01.08.2017].

22. Fusar-Poli P, Klersy C, Stramesi F, Callegari A, Arbustini E, Politi P. Determinants of quality of life in Marfan syndrome. Psychosomatics 2008, 49: 243-248.

23. Dalman RL, Mell M. Management of asymptomatic abdominal aortic aneurysm. www.uptodate.com/contens/management-of-asymptomatic-abdominal-aortic-aneurysm [Available at: 01.08.2017].

24. Kościelak R. Health locus of control and conviction of self-efficacy in health and sickness. Impuls, Krakow 2010.

25. Kübler-Ross E. On death and dying. Abingdon, Routlege 2009. 